\title{
Acoustic Performance from a Mixture of Plastic Waste, Wood Dust, and Rice Husk
}

\author{
Nur Rahmawati Syamsiyah*, Dhani Mutiari, Yayi Arsandrie, Suharyani, Saidah Aliyatul Himmah
}

Department of Architecture, Universitas Muhammadiyah Surakarta, Surakarta, Indonesia

Received February 25, 2020; Revised June 24, 2020; Accepted July 7, 2020

Copyright $\odot 2020$ by authors, all rights reserved. Authors agree that this article remains permanently open access under the terms of the Creative Commons Attribution License 4.0 International License

\begin{abstract}
Indonesia is a country with the second-largest amount of plastic waste into sea pollution in the world. The volume of Indonesia's plastic waste imports in 2018 reached 320 thousand tons. To reduce plastic waste, the processing innovations need to be done, and one of them is for building material in the form of a brick. This study used a mixture of plastic waste, sawdust, and rice husk with cement adhesive through a specific ratio. The research aims to test the ability of concrete blocks to absorb sound. The research method used was the test of sound absorption ability by 20 samples of brick making test material. The sound source was generated from the shotgun. Then the sound recorded by the dodecahedron microphone which was connected to Adobe Audacity software. Processing impulse response data used the Real-Time Analyzer program. The concrete test material was made from a mixture of plastic, sawdust and rice husk in a ratio of 30/70, 50/50, and 40/60. The sound absorption test was carried out in an enclosed $3.5 \times 3.5 \mathrm{~m}^{2}$ acoustic laboratory. The concrete block, which was a mixture of plastic and rice husk with a ratio of 30/70, was the best material for absorbing sound. The sound could be absorbed up to 1.2 decibels, while the mixture of plastic and rice husk with a ratio of $60 / 40$ was the lowest material in the ability to absorb sound. High-capacity concrete blocks could not only absorb the noise but also be used as building space separating materials.
\end{abstract}

Keywords Bricks, Plastic Waste, Rice Husk, Sawdust, Sound Absorption

\section{Introduction Section}

Waste in human life is increasing in number and variety, both organic and inorganic waste. The increase in the quantity of waste is caused by the use of goods in daily life.
The nature of plastics is practical and economical. It is caused by plastics that are often used as a disposable item. So the more plastics are used, the more plastic waste is produced. It has caused the amount of inorganic waste to increase continuously and become a severe environmental problem. Indonesia is a country with the second-largest amount of plastic waste into sea pollution in the world. The volume of Indonesia's plastic waste imports in 2018 reached 320 thousand tons. This number which increased $150 \%$ from the previous year due to the state of China was no longer an importer of plastic waste, so the impact also entered Indonesia.

Research on plastic waste has been carried out, especially processing plastic into building materials. Pramono (2014) used the clay to processing plastics into bricks. The plastic used was the type of LDPE, PE-HD, and PVC. Percentage of $20-30 \%$ plastic waste produced Class I of bricks with the highest compressive strength above $100 \mathrm{~kg} / \mathrm{cm}^{2}$. Sellakutty (2016) made bricks from processed plastic waste, river sand, and aggregates derived from iron oxide. Tests carried out on these bricks were compressive strength, ability to absorb water, resistance to fire, and scratch resistance. This specification brought these mixed bricks into a high-quality bricks category. Singhal (2018) produced bricks and tiles from a mixture of crushed clay and plastic. The advantage was that bricks and tiles became lighter, smoother, and had better water absorption. Types of lightweight bricks were also produced from Ramadan's research (2017), which used LDPE type plastics. It was similar to Kognole's (2019) research, which used mixing clay with HDPE and PET plastic waste. PET was the choice because this type of plastic could only be used once so that this type of plastic waste was very abundant. Kognole's research was the development of Hombal's research (2018), which used clay and only PET plastic types to make bricks. The processing of plastic and clay waste into bricks was intended to be a compressive strength test. The main result was the number of plastic granules 0.5 $\mathrm{cm}-0.75 \mathrm{~cm}$ affected the compressive strength. Not only 
clay, apparently, but there were also other mixed variations, namely plastic waste and water hyacinth plants. This research was conducted by Said (2016). It produced wall material from plastic waste that had a very high level of strength and tenacity so that it was best used as wall material, doors, and even as a floor and ceiling material. Basuki (2018) made a D classification paving block according to the Indonesian national standard SNI 03-0691-1989. The paving block was made from processed plastic waste and used for the yard. The type of plastic waste used was hard and resilient, such as bottles and caps, so that this paving block experienced a compressive strength test and categorized as useful.

This paper is the result of the research with the novelty of research on processing waste plastic types of High-density polyethylene (HDPE) and polypropylene (PP) mixed with wood dust and rice husk. The study focused on the comparison of plastic raw materials and mixed materials. The selection of HDPE and PP plastic types was due to the plastic being stiffer, stronger, moisture resistant sturdy, and heat resistant. It is different from the generality of other studies, which have been explained above, where many used the types of High-density polyethylene (HDPE) and Low-density polyethylene (LDPE). Other studies also used a comparison of plastic raw materials and their mixtures, but the comparison was different from the comparison used in this study. Comparisons in this study considered mixed materials with more types and all derived from waste. Differences in the use of plastic types were due to differences in the use of mixed materials and research purposes.

Based on the explanation above, this research is an innovation of sound-absorbing material from waste plastic, rice husk, and sawdust. The innovation obtained is the right comparison between plastics and their mixtures, so that the bricks produced from these mixtures have a good performance from the acoustic aspect, especially the sound absorption performance.

\section{Method}

\section{Research Materials}

The main ingredients of the research were high-density polyethylene (HDPE) and polypropylene (PP) plastic waste, which had been gently cut. HDPE plastic waste came from used oil bottles, gallons of drinking water, medicine bottles, and shampoo bottles, which was the colorful plastic waste. Meanwhile, PP waste was from mineral water packaging and biscuit packaging with clear white characteristics. Plastic mixed material was in the form of rice husk and sawdust from various types of wood. The adhesive used PC cement and white cement. Research materials can be seen in Figure 1, and brick making tools can be seen in Figure 2.

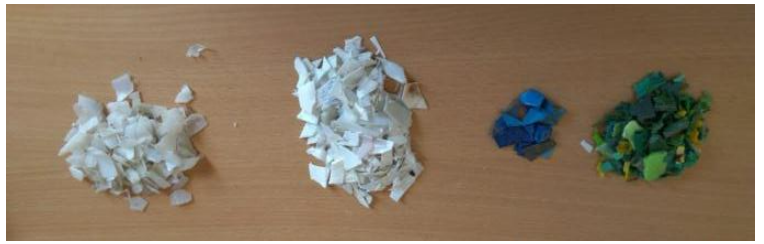

(a)

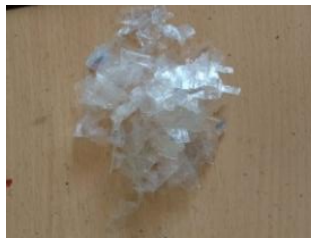

(b)

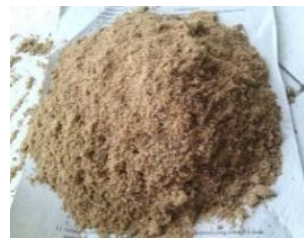

(c)

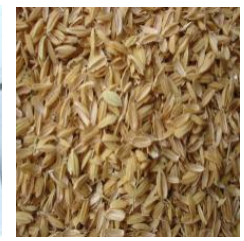

(d)

Figure 1. Research materials: (a) HDPE type plastic waste, (b) PP plastic waste, (c) sawdust, and (d) rice husk

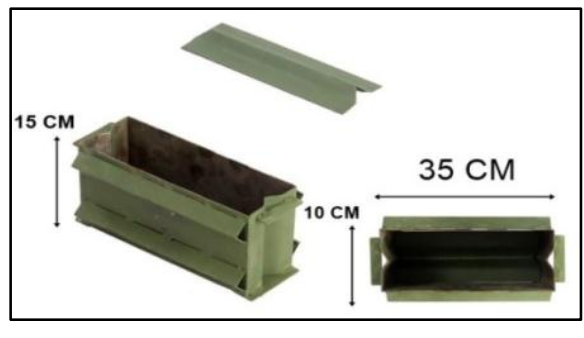

(a)

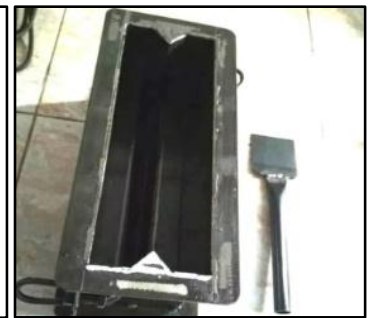

(b)

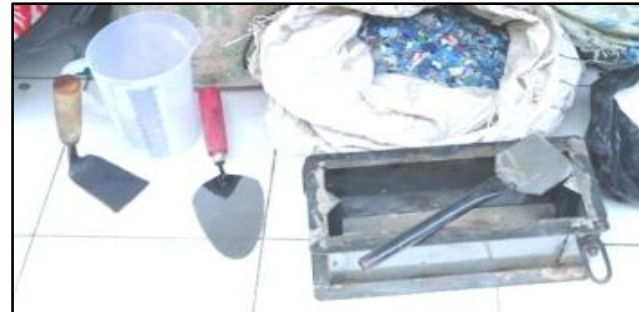

(c)

Figure 2. Supporting tools: (a) and (b) brick making and (c) shovel and measuring cup equipment 
The comparison of the mixture of plastic waste, rice husk, and sawdust affected the results of the study. Therefore, to get the precision of the result, the mixture of plastic waste was made in such a variation. There were 20 test materials or test samples, which were obtained from the comparison of the main ingredients, mixing ingredients, and adhesives, with the following ratios in Table 1.

There were two adhesives, namely PC cement and white cement. PC cement adhesive worked for a mixture of plastic waste and sawdust or rice husk, with a total volume of $9325 \mathrm{ml}$ for each one concrete block. Meanwhile, the white cement adhesive functioned for a mixture of plastic waste, sawdust or rice husk, cement, water, and fox glue, with a total volume of $8400 \mathrm{ml}$ mixed material for every one-concrete block. The volume of PC cement adhesive was more than the volume of white cement adhesive. The addition of the volume of each material was intended to obtain the same brick dimensions so that it could be compared. Figure 3 is a brick sample that was successfully made and ready to be tested for sound absorption.

Table 1. Comparison of the main ingredients of plastic waste and their mixtures

\begin{tabular}{|c|c|c|c|c|c|c|c|c|c|}
\hline \multirow[b]{2}{*}{ No } & \multirow[b]{2}{*}{ Type of Material Mixture } & \multicolumn{3}{|c|}{ The mix of Main Ingredients } & \multicolumn{2}{|c|}{ PC Cement } & \multicolumn{3}{|c|}{ White Cement Adhesives } \\
\hline & & $\begin{array}{l}\text { Plastic } \\
\quad(\mathrm{ml})\end{array}$ & $\begin{array}{c}\text { Rice } \\
\text { Husk } \\
(\mathrm{ml})\end{array}$ & $\begin{array}{l}\text { Sawdust } \\
\quad(\mathrm{ml})\end{array}$ & $\begin{array}{l}\text { Cement } \\
(\mathrm{ml})\end{array}$ & $\begin{array}{l}\text { Water } \\
(\mathrm{ml})\end{array}$ & $\begin{array}{l}\text { Cement } \\
(\mathrm{ml})\end{array}$ & $\begin{array}{c}\text { Fox } \\
\text { Glue } \\
\text { (gr) }\end{array}$ & $\begin{array}{l}\text { Water } \\
(\mathbf{m l})\end{array}$ \\
\hline 1 & $\begin{array}{l}\text { Plastic and rice husk } 70 / 30 \text { with } \\
\text { PC cement adhesive }\end{array}$ & 3735 & 1600 & & 2660 & 1330 & & & \\
\hline 2 & $\begin{array}{c}\text { Plastic and rice husk } 70 / 30 \text { with } \\
\text { white cement adhesive }\end{array}$ & 2800 & 1200 & & & & 2000 & 400 & 2000 \\
\hline 3 & $\begin{array}{l}\text { Plastic and sawdust } 30 / 70 \text { with } \\
\text { white cement adhesive }\end{array}$ & 1200 & & 2800 & & & 2000 & 400 & 2000 \\
\hline 4 & $\begin{array}{l}\text { Plastic and rice husk } 30 / 70 \text { with } \\
\text { PC cement adhesive }\end{array}$ & 1600 & 3735 & & 2660 & 1330 & & & \\
\hline 5 & $\begin{array}{l}\text { Plastic and rice husk } 30 / 70 \text { with } \\
\text { white cement adhesive }\end{array}$ & 1200 & 2800 & & & & 2000 & 400 & 2000 \\
\hline 6 & $\begin{array}{l}\text { Plastic and sawdust } 30 / 70 \text { with } \\
\text { PC cement adhesive }\end{array}$ & 1600 & & 3735 & 2660 & 1330 & & & \\
\hline 7 & $\begin{array}{l}\text { Plastic and rice husk } 40 / 60 \text { with } \\
\text { PC cement adhesive }\end{array}$ & 2135 & 3200 & & 2660 & 1330 & & & \\
\hline 8 & $\begin{array}{l}\text { Plastic and sawdust } 40 / 60 \text { with } \\
\text { PC cement adhesive }\end{array}$ & 2135 & & 3200 & 2660 & 1330 & & & \\
\hline 9 & $\begin{array}{c}\text { Plastic and rice husk } 40 / 60 \text { with } \\
\text { white cement adhesive }\end{array}$ & 1600 & 2400 & & & & 2000 & 400 & 2000 \\
\hline 10 & $\begin{array}{c}\text { Plastic and sawdust } 40 / 60 \text { with } \\
\text { white cement adhesive }\end{array}$ & 1600 & & 2400 & & & 2000 & 400 & 2000 \\
\hline 11 & $\begin{array}{l}\text { Plastic and sawdust 70/30 with } \\
\text { PC cement adhesive }\end{array}$ & 3735 & & 1600 & 2660 & 1330 & & & \\
\hline 12 & $\begin{array}{c}\text { Plastic and sawdust 70/30 with } \\
\text { white cement adhesive }\end{array}$ & 2800 & & 1200 & & & 2000 & 400 & 2000 \\
\hline 13 & $\begin{array}{l}\text { Plastic and rice husk } 60 / 40 \text { with } \\
\text { white cement adhesive }\end{array}$ & 2400 & 1600 & & & & 2000 & 400 & 2000 \\
\hline 14 & $\begin{array}{l}\text { Plastic and rice husk } 60 / 40 \text { with } \\
\text { PC cement adhesive }\end{array}$ & 3200 & 2135 & & 2660 & 1330 & & & \\
\hline 15 & $\begin{array}{c}\text { Plastic and sawdust } 60 / 40 \text { with } \\
\text { white cement adhesive }\end{array}$ & 2400 & & 1600 & & & 2000 & 400 & 2000 \\
\hline 16 & $\begin{array}{l}\text { Plastic and sawdust } 60 / 40 \text { with } \\
\text { PC cement adhesive }\end{array}$ & 3200 & & 2135 & 2660 & 1330 & & & \\
\hline 17 & $\begin{array}{l}\text { Plastic and rice husk } 50 / 50 \text { with } \\
\text { white cement adhesive }\end{array}$ & 2000 & 2000 & & & & 2000 & 400 & 2000 \\
\hline 18 & $\begin{array}{l}\text { Plastic and rice husk } 50 / 50 \text { with } \\
\text { PC cement adhesive }\end{array}$ & 2665 & 2665 & & 2660 & 1330 & & & \\
\hline 19 & $\begin{array}{c}\text { Plastic and sawdust } 50 / 50 \text { with } \\
\text { white cement adhesive }\end{array}$ & 2000 & & 2000 & & & 2000 & 400 & 2000 \\
\hline 20 & $\begin{array}{l}\text { Plastic and sawdust 50/50 with } \\
\text { PC cement adhesive }\end{array}$ & 2665 & & 2665 & 2660 & 1330 & 2000 & 400 & 2000 \\
\hline
\end{tabular}

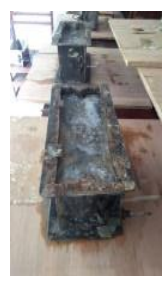

(a)

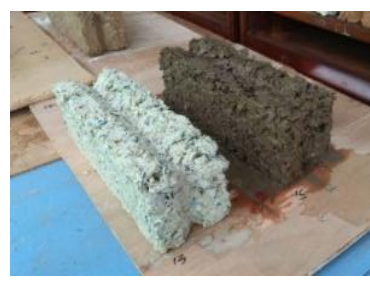

(b)

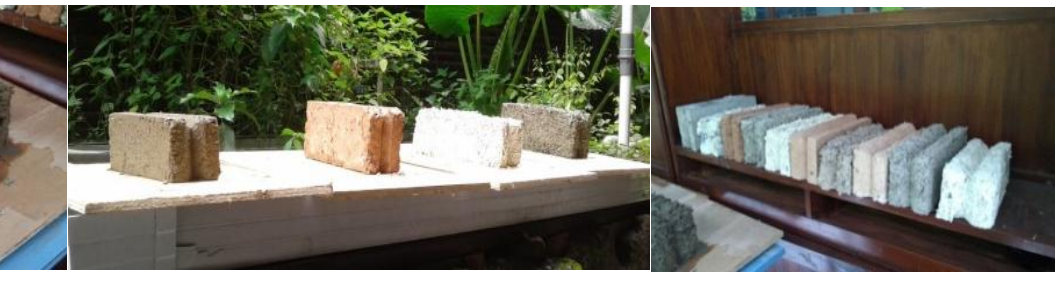

(c) (d)

Figure 3. The brick processes are produced until they are ready to be tested: (a) brick molding process, (b) bricks released from the mold, (c) brick drying process, (d) brick storage ready for testing 


\section{Research Tools}

This study aims to examine the ability of the material to absorb sound. Therefore, it was needed a sound source in the form of a gun sound produced from a laptop, with a sound strength of $83 \mathrm{~dB}$. Research tools needed are as below:

1. Microphone (2 units), capable of capturing waves from all directions (omnidirectional).

2. Calibrator (1 unit), which functioned as a calibration tool so that the data read from the laptop matched what was received by the microphone. Calibrators were used before and after measurement.

3. Signal conditioning BSWA MC3022 (1 unit), as a store of sound before entering the program on a laptop.

4. Thermohygrometer (1 unit), for measuring the thermal test chamber.

5. Sound level meter/SLM (1 unit) to measure the sound strength from the source.

6. Laptops (2 units) that were equipped with Real-Time Analyze software, Adobe Audacity, and sound sources.

7. Tripod (2 units) as microphone support.

8. Connecting cables between electro-acoustic instruments (1 unit).

The main equipment in the study can be seen in Figure 4 .

\section{Procedure}

The shotgun sound was received by an omnidirectional microphone, as a device that could receive sounds from all directions. A cable connected the microphone to the signal conditioning, and then the signal conditioning was connected to the laptop with the Adobe Audacity program. The signal data from Adobe Audacity was processed in a real-time analyzer program to obtain impulse response data. Impulse response data was in the form of sound pressure level value (SPL). SPL value in RTA Realtime Analyzer was still in dBFS (dB full scale) units which were negative. This unit must be changed by adding a dynamic range of $+96 \mathrm{~dB}$ to the $\mathrm{dBFS}$ value. The value of $+96 \mathrm{~dB}$ was due to a $16 \mathrm{bit} / 44.1 \mathrm{kHz}$ (mono/stereo) setting on the microphone gauge. Dynamic range describes the softest to the loudest sound range. Absorption ability of materials was obtained from the difference in the value of the SPL between the empty condition test chamber without the test material and the condition test chamber containing test material.

The test chamber measured $3.6 \mathrm{~m} \times 3.6 \mathrm{~m}$ with wall and roof elements made of multiplex panel material, the space between the two multiplex walls of $5 \mathrm{~cm}$. The floor used a thin carpet. Ambient temperature was around $27^{\circ} \mathrm{C}$, and the relative humidity was approximately $58 \% \mathrm{RH}$. The room met the requirements for testing because there was undoubtedly no other sound sources, other than the sound source of the shotgun. The test chamber had a reverberation time of 2.743 seconds, meaning that the chamber had a high enough reverberation and was in accordance with the requirements of the test chamber. The conditions of the space and the process of taking the test data for the absorption of the test material can be seen in Figure 5.

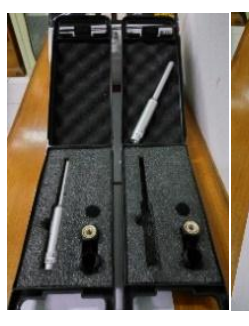

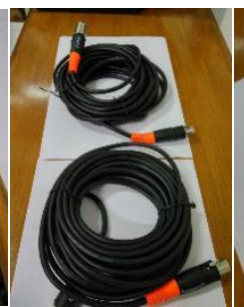

(a)

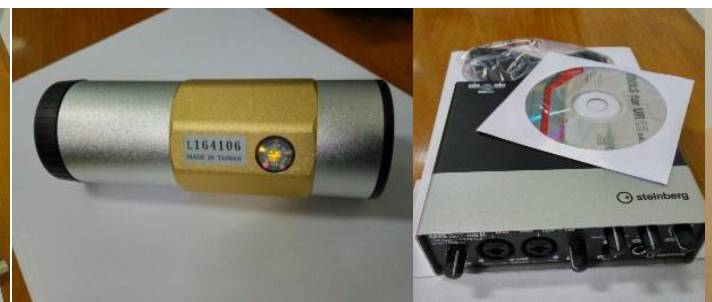

(b) (c)

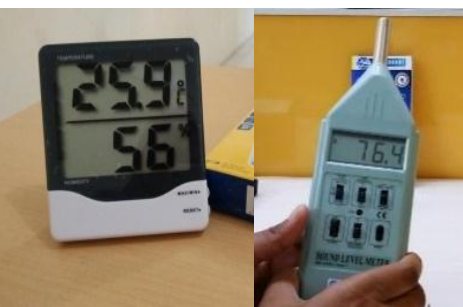

(d) (e)

Figure 4. Research tools: (a) omnidirectional microphone, (b) calibrator, (c) signal conditioning, (d) thermohygrometer, and (e) sound level meter

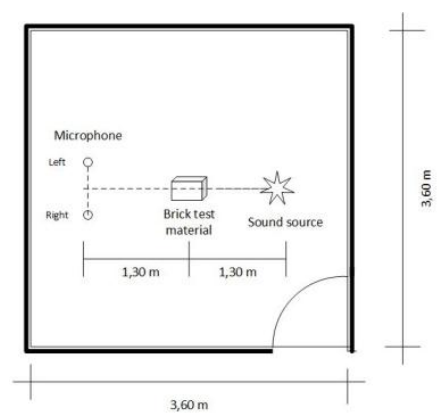

(a)

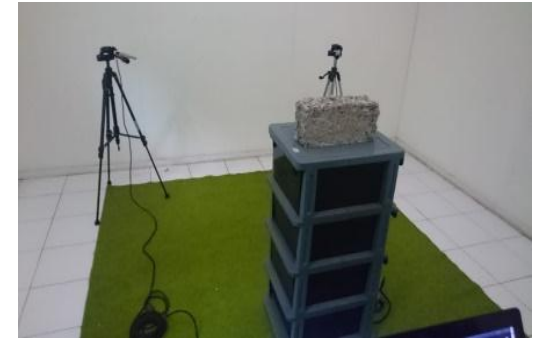

(b)

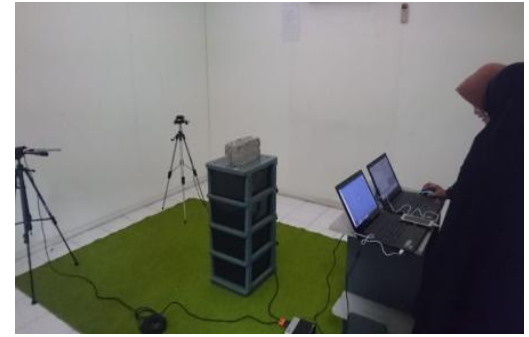

(c)

Figure 5. Test chamber and the process of sound-absorption test data collection: (a) the test room plan, (b) and (c) the testing process 
The procedure details can be seen below:

1. The understanding of the existing floor plan/room and research objects, as well as existing room components.

2. The preparation of the measuring instruments and specimens (bricks) is conducted.

3. Determination of the placement of the microphone one meter from the floor, according to the height of the test sample and the sound source. Naming for each microphone position with the label Left (L) and Right (R).

4. Ensure that there were no active sources of sound in the room, such as speech sounds and electronic devices.

5. Sounding the shotgun, and began the measurement of the reverberation time and sound pressure level (SPL) conditions without any test material.

6. Data collection by using Audacity software is carried out in the room.

7. They did performing signal processing and data analysis with real-time analyzer software that produced acoustic parameters. The frequency range read on the impulse response graph was from $63 \mathrm{~Hz}$ to $16000 \mathrm{~Hz}$ and $1 / 3$ octave filter.

8. It existed the same as measurement number (5), repeating the reverberation time and SPL measurement by placing 1-20 test material in the available place. Each material was tested 3 times, and the value taken is average.
9. The difference in reverberation time and SPL between numbers (7) and (5) of each test material indicated the absorption ability of the test material.

\section{Result and Discussion}

The acoustic parameters of the reverberation time of $\mathrm{T}_{30}$ were performed by measuring the impulse response. This measurement is one way to find out the acoustic performance of a room (in this case, the acoustic test chamber was a reference for the performance of the test material). From this measurement, we will get a picture of the interaction between the sound source and the surface in the room, which can be illustrated in the time sequence pattern of the reflection of sound energy at a point in the room and the reduction of sound energy at any time (Beranek, 2004, p.20; Kleiner \& Tichy, 2014, p.102). The reverberation time is mostly used at frequencies of 500 and $1000 \mathrm{~Hz}$ (Beranek, 2004, p. 577).

Based on measurements, when space was obtained, the $\mathrm{T}_{30}$ reverberation time was 2,743 seconds at $1000 \mathrm{~Hz}$ frequency as the sound frequency, and the SPL value of the test chamber when without test material was $52.88 \mathrm{~dB}$. This SPL value was used as a reference to calculate the amount of sound absorption ability of the test material, by calculating the difference between the SPL of space and the SPL of each test material in the chamber. The results of the reverberation and SPL measurement results are as in Table 2.

Table 2. Reverberation time values $\left(\mathrm{T}_{30}\right)$ and SPL of test material

\begin{tabular}{|c|c|c|c|c|}
\hline No & Type of Material Mixture & $\begin{array}{c}\text { Reverberation time T } 30 \\
\text { (second) }\end{array}$ & SPL (dB) & Absorption (dB) \\
\hline 1 & Plastic and rice husk 70/30 with PC cement adhesive & 2.968 & 53.26 & 0.38 \\
\hline 2 & Plastic and rice husk 70/30 with white cement adhesive & 2.835 & 52.75 & 0.13 \\
\hline 3 & Plastic and sawdust 30/70 with white cement adhesive & 3.007 & 52.35 & 0.53 \\
\hline 4 & Plastic and rice husk 30/70 with PC cement adhesive & 2.728 & 52.35 & 0.53 \\
\hline 5 & Plastic and rice husk 30/70 with white cement adhesive & 3.454 & 52.90 & 0.02 \\
\hline 6 & Plastic and sawdust 30/70 with PC cement adhesive & 0.468 & 51.68 & 1.2 \\
\hline 7 & Plastic and rice husk 40/60 with PC cement adhesive & 3.184 & 52.88 & 0 \\
\hline 8 & Plastic and sawdust $40 / 60$ with PC cement adhesive & 2.152 & 52.73 & 0.15 \\
\hline 9 & Plastic and rice husk $40 / 60$ with white cement adhesive & 3.070 & 53.05 & 0.17 \\
\hline 10 & Plastic and sawdust $40 / 60$ with white cement adhesive & 3.268 & 53.06 & 0.18 \\
\hline 11 & Plastic and sawdust 70/30 with PC cement adhesive & 2.859 & 52.98 & 0.1 \\
\hline 12 & Plastic and sawdust 70/30 with white cement adhesive & 1.512 & 52.98 & 0.1 \\
\hline 13 & Plastic and rice husk $60 / 40$ with white cement adhesive & 1.391 & 53.64 & 0.76 \\
\hline 14 & Plastic and rice husk 60/40 with PC cement adhesive & 2.778 & 53.02 & 0.14 \\
\hline 15 & Plastic and sawdust $60 / 40$ with white cement adhesive & 2.891 & 53.19 & 0.31 \\
\hline 16 & Plastic and sawdust $60 / 40$ with PC cement adhesive & 2.834 & 53.02 & 0.14 \\
\hline 17 & Plastic and rice husk 50/50 with white cement adhesive & 2.996 & 52.91 & 0.03 \\
\hline 18 & Plastic and rice husk 50/50 with PC cement adhesive & 2.884 & 52.78 & 0.1 \\
\hline 19 & Plastic and sawdust 50/50 with white cement adhesive & 1.740 & 53.50 & 0.62 \\
\hline 20 & Plastic and sawdust 50/50 with PC cement adhesive & 3.031 & 52.90 & 0.02 \\
\hline
\end{tabular}


The identification of the sound absorption ability of the test material was through the lowest value of the $T_{30}$ reverberation time. The lowest $T_{30}$ value means that the test material can absorb sound in the fastest time (units of seconds). The lowest $T_{30}$ reverberation time was mixed material with a ratio of $30 \%$ plastic to $70 \%$ sawdust with PC cement adhesive, with a reverberation time of 0.468 seconds. Whereas, the worst test material in absorbing sound was the ratio of $70 \%$ plastic to $30 \%$ sawdust with white cement adhesive, with a reverberation time of 3,454 seconds. SPL value of $30 \%$ plastic material and $70 \%$ sawdust was 51.68 decibels. The absorption column in Table 2 shows the difference between the SPL value of the test material and SPL when empty space was obtained. The difference in value was as an indicator of the magnitude of the material's ability to reduce the sound energy that reached it (in decibels). Table 2 shows that the PC cement and white cement adhesives influence the reverberation time value of $T_{30}$. The test materials with white cement adhesives as much as $60 \%$ produce $\mathrm{T}_{30}$ higher than PC cement. White cement contains high silica and sulphur trioxide $\mathrm{SO}_{3}$ (Purnawan \& Prabowo, 2017) so that the adhesive power is stronger and fewer pores and longer in sound absorption. Thus the PC cement is better at absorbing sound than the white cement. White cement is a product of the highest technology that can be achieved by the cement industry. Not only the grinding of powder is expensive but also the raw material, so white cement is an expensive type of Portland cement. Therefore economic considerations are needed, and besides high costs, it turns out to be less good also in terms of sound absorption techniques. The gain of $T_{30}$ and SPL values was clarified by the graph visualization, as shown in Figures 6 .

In Figures 6, graphs appear to decrease dramatically and consistently at the same point (point 6), both in the reverberation time value $(0.468$ seconds $)$ and the compressive strength value of the sound $(51.68 \mathrm{~dB})$. The lowest point indicated the smallest number of reverberation times or the shortest amount of time required for the test material to absorb sound. It means that the absorption value of the test material was high, whereas, the lowest point on the SPL graph shows the lowest sound captured by the microphone. The lowest value of the SPL indicated that the test material had the best sound absorption ability. The ability of the material to reduce sound to $1.2 \mathrm{~dB}$, which was obtained from the difference between the initial SPL value when empty space was obtained, was $52.88 \mathrm{~dB}$ with the SPL value when space was filled with test material 51.68 dB. Point number 6 was the test material in the form of $30 \%$ plastic waste mixed with $70 \%$ wood dust, with an adhesive in the form of PC cement. The test material was very fast in absorbing sound with a time of only 0.468 seconds and could reduce sound (or the ability to absorb sound) to reach $1.2 \mathrm{~dB}$ in a short time with high sound absorption. The surface of plastic waste material mixed with wood sawdust looked hollower so that energy absorption was faster. The effect of grey cement (PC cement) adhesive supported the sound absorption process when compared to white cement adhesive.

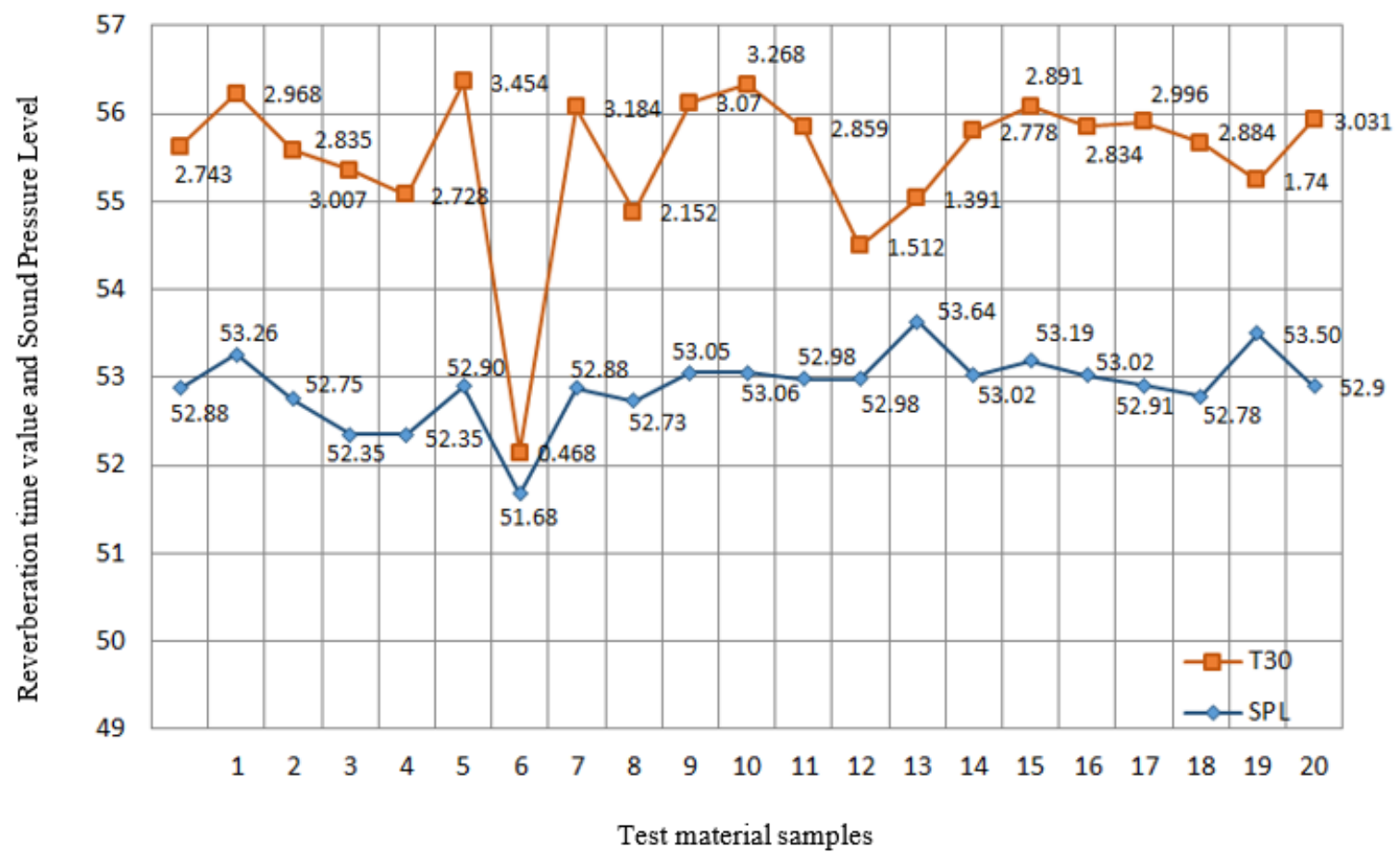

Figure 6. Graph of $\mathrm{T}_{30}$ reverberation time value (seconds) and SPL sound pressure level value (decibel) of test material samples 
What is the state of the other test material? As for the answer, it needs to be ensured that there is public awareness. Actually, this research is not just looking for wood dust or rice husk waste as a test material, which can function to absorb sound. Still, more than that, it can provide awareness to the community so that they conduct good management in the management of waste around the environment. Good waste management will have the effect of ease in utilizing the waste to be reprocessed into some form of building material or other object functions. The European Union (EU) takes action to improve the management of plastic recycling. Even the most promising and sustainable future scenarios for waste plastic management in Sweden include high targets for recycling in line with EU targets - and the gradual elimination of plastic burning as a waste management option (Milios, 2018).

Management of plastic waste and other waste will be good if the characteristics of the waste are understood. Understanding the character of the material would be part of the virtues of this research. The different texture between sawdust and rice husk would also be different sound effects captured by the measuring instrument. The plastic waste used in this research was a mixed rice husk and sawdust. The brick surface of the rice husk mixture has a rougher texture, compared to bricks from a mixture of sawdust. Eadkhong Research (2019) found that rice husk panels had a 0.97 absorption ability, an almost perfect absorption value. This finding is in accordance with the opinion of Egan (1988), who stated that where the surface is rough, and even hollow has a better absorption ability. Previously, Ismail (2015) tested the ability of rice husks and sugar cane to make sustainable acoustic pancakes by bonding them using phenol-formaldehyde (PF). Acoustic panels made from a mixture of $100 \%$ rice husk had a higher absorbency co-efficient when compared to the performance of other samples that had less rice husk content. The fact that the characteristics of rice husks have air gaps, in which the spongy nature has created much empty space, encourages more sound absorption ability due to porous surfaces. Sound absorption is strongly influenced by the availability of the porosity level of the panel. However, the study that authors have done to the bricks from a mixture of plastic and rice husk found that the ratio of $30 \%$ cement and $70 \%$ rice husk apparently only had a sound absorption ability of $0.53 \mathrm{~dB}$, which could achieve only half of the achievements when compared to plastic and sawdust. Half of the material was only a mixture of plastic and sawdust. A comparison of the $T_{30}$ value of a mixture of plastic material, rice husk, and sawdust with grey adhesive (PC cement) can be seen in Figure 7.

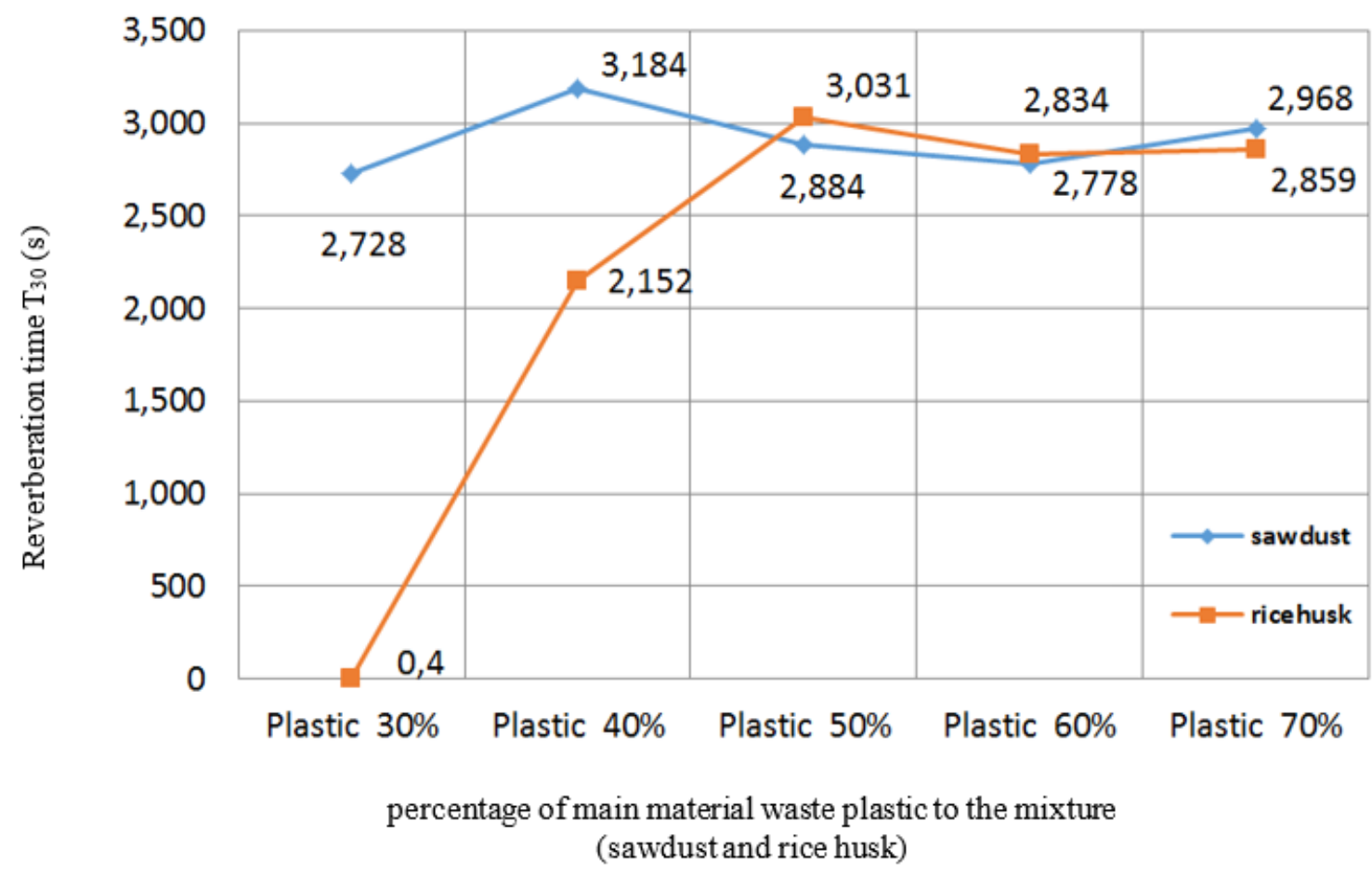

Figure 7. Comparison of reverberation time $\mathrm{T}_{30}$ between waste plastics-sawdust with plastic waste and rice husk with PC cement adhesive 
Figure 7 reinforces the above statement that sawdust has a better sound absorption ability than rice husks. In the composition of $60 \%$ plastic, it turned out that $40 \%$ of sawdust could reduce $0.14 \mathrm{~dB}$ of sound from the initial sound source. This value is indeed not very significant because it is too small under $1 \mathrm{~dB}$. However, this study has clearly demonstrated the added value of wood sawdust waste material, which is very good for use as sound absorption material. This study is in accordance with the Guzman Research (2015), which used 49\% plastic LDPE type, $49 \%$ wood powder, and 2\% Fusabond adhesive. Guzman has proven the sound absorption ability of sawdust with a modified brick design. Guzman's research used four brick shapes, and it turned out that bricks with triangular holes in the middle could be passed longer, rather than hexagonal shaped holes. Triangular bricks could reduce the noise of $3 \mathrm{~dB}$ lower than hexagonal bricks. The triangle hole captured the sound of $43.9 \mathrm{~dB}$, while the hexagon hole captured the sound of $46.4 \mathrm{~dB}$. The results of this Guzman study strengthen the results of research conducted on a mixture of sawdust and plastic. Furthermore, Figure 7 shows that plastic waste that fills bricks with increasing levels, starting at 50\%,60\%, and $70 \%$, will have almost the same reverberation time, both in a mixture of rice husk and sawdust.

Both wood sawdust and rice husk had a reverberation time value of almost the same, which were 2.778 and 2.834 seconds; if the plastic waste had a percentage of $60 \%$, the mixed material was $40 \%$. A significant difference was in the ratio of $30 \%$ plastic waste and $70 \%$ sawdust or rice husk. The surface condition of rice husk material cannot be a good sound absorber. Especially in large amounts, where $70 \%$ of rice husk and $30 \%$ plastic, it turned out that this material was more reflective. This statement can be seen with a high reverberation time of 2.728 seconds. A temporary conclusion was that wood sawdust was far better at absorbing sound than rice husks. This comparison will be more visible with the gain of SPL data, as shown in Figure 8.

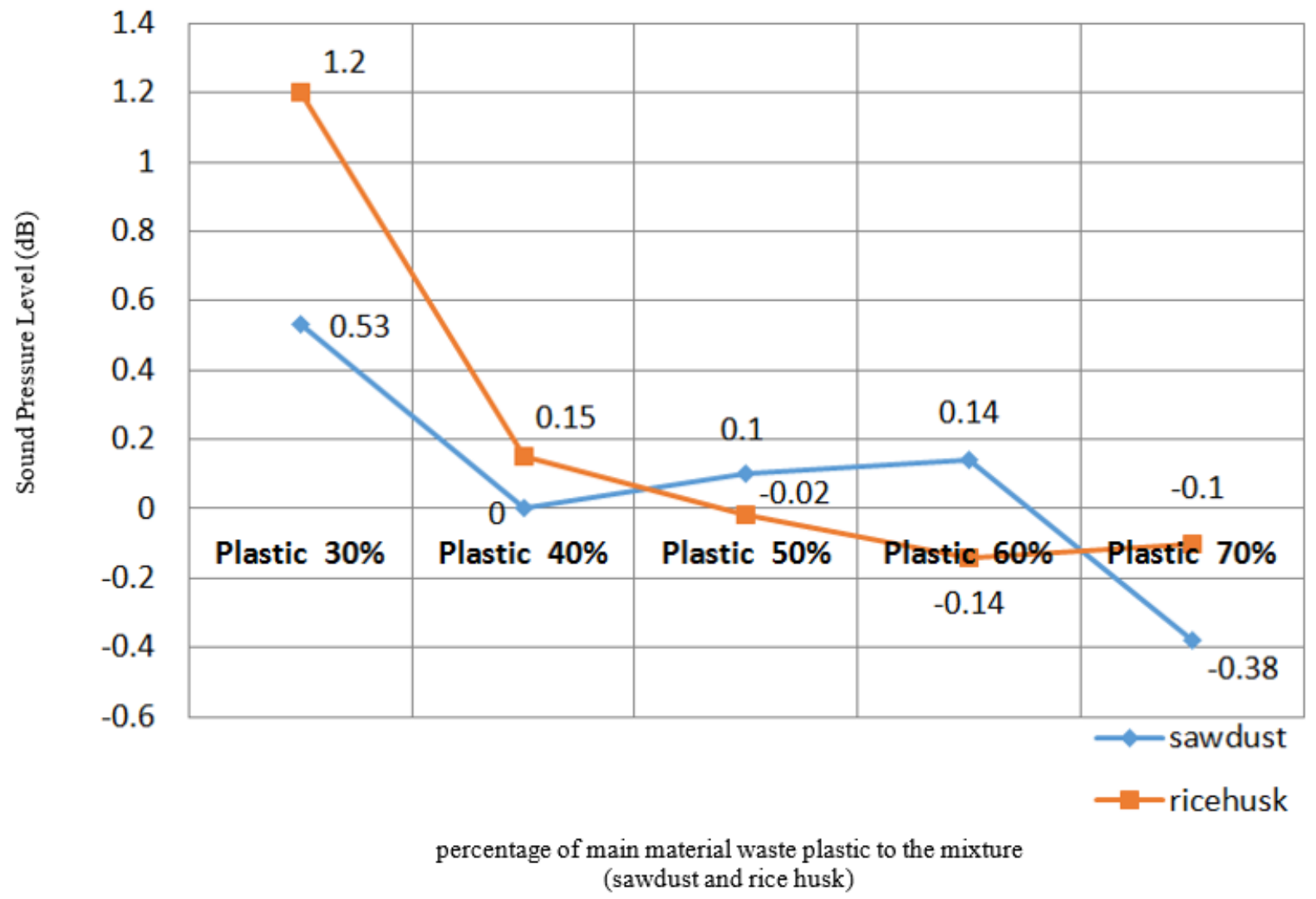

Figure 8. The comparison of test material: plastic waste-sawdust with plastic waste-rice husk in the SPL value difference between the empty space and the space containing the test material 
This research is an innovation from a mixture of waste materials that are easily found in everyday life. In the study, through testing plastic waste and a mixture of sawdust and rice husk, was directly carried out in the room, became a directly visible effect on the overall space. Not only the sound aspect but also the thermal aspect can be felt. The composition of alternative brick materials from plastic waste and sawdust or rice husk can absorb heat from outdoor temperatures at night better than during the day. It is evidenced by the higher temperature difference between outdoor and indoor temperatures at night measurements. The character of sawdust and rice husk can affect the results of thermal measurements during the day and night (Arsandrie et al., 2019). It means that the test material for the mixture of plastic waste and sawdust and rice husk waste is suitable for use in the home and will provide comfort. On the one side, it has the advantage of absorbing noise, and on the other side, it is not affected by outside temperatures during the day, and at night, the room's thermal state can be well-conditioned.

The geometric shape of the room and the finishing elements of the room will be easily adjusted with this test material. Plastic and sawdust have a predominantly soft orange brick colour. The arrangement of these bricks in a room will provide visual comfort.

\section{Conclusions}

This research is an innovation of sound-absorbing material made from a mixture of plastic waste, rice husk, and sawdust in a specific ratio. The research resulted in a ratio of a mixture of $70 \%$ sawdust and $30 \%$ plastic was the best for absorbing sound. The mixing process and the characteristics of the mixture determine the quality of the performance of the bricks according to the purpose of the study. Sawdust powder can make bricks have a smooth texture, and in fact, have a better sound reduction performance, which can reduce sound by $1.2 \mathrm{~dB}$. Meanwhile, compared with rice husk, it has a coarser and hollow textured and can only reduce the sound of $0.53 \mathrm{~dB}$. SPL value of a mixture of sawdust and plastic reached $51.68 \mathrm{~dB}$. The SPL value is still in accordance with a maximum conversation standard of $60 \mathrm{~dB}$. The reverberation time of a mixture of sawdust and plastic reached 0.468 seconds, while the $\mathrm{T}_{30}$ standard for the conversation space was 0.5 seconds. A comparison of $30 \%$ plastic waste mixture and $70 \%$ sawdust is the most effective way to produce sound absorption.

The innovations that can be developed from the bricks of this research is that the size of $35 \mathrm{~cm} \times 15 \mathrm{~cm} \mathrm{x} 10 \mathrm{~cm}$ is effective enough to make the walls of the house, both outer and inner walls. The smooth texture and soft orange color seem to be visually appealing. Especially when natural wood doors or windows installed, color harmonization will appear, and there will be the beauty of space.

\section{Acknowledgements}

I would like to gratitude to the Doctoral Grant Research Program from LPPM Universitas Muhammadiyah Surakarta (UMS). We also give praise to students of Building Science Laboratory, who helped in acoustics measurements.

\section{REFERENCES}

[1] Arsandrie, Y., Mutiari, D., Syamsiyah, N. R., Suharyani, S., \& Himmah, S. A. (2019). Thermal Insulation of Alternative Bricks Material from Plastic Waste Mixtured with Sawdust and Ricehuks. Proceedings of The International Conference on Engineering and Advancement in Technology. Sorong: Universitas Muhammadiyah Sorong.

[2] Basuki, B., \& Darmanijati. (2018). Pemanfaatan Limbah Plastik Bekas untuk Bahan Utama Pembuat Paving Block. Jurnal Rekayasa Lingkungan Volume 18 Nomor 1, 1-7.

[3] Beranek, L. (2004). Concert Halls and Opera Houses (Music, Acoustics and Architecture). New York: Springer.

[4] Eadkhong, T., Thida, W., \& Danworaphong, S. (2019). Sound Absorption Characteristics of Husk. 5th International conference on Engineering, Applied Sciences and Technology (ICEAST) (p. DOI: 10.1109/ICEAST.2019.880 2573). Laos: King Mongkut's Institute of Technology Ladkrabang.

[5] Egan, D. M. (1988). Architectural Acoustics. New York: Mc Graw-Hill Book Company.

[6] Guzman, A. M., \& Munno, M. T. (2015). Design of a Brick With Sound Absorption Properties Based on Plastic Waste and Sawdust. IEEE Journals (open access publishing) Vol. 3, 1260-1271.

[7] Hombal, R., LG., S., K., P., \& Gatti, R. R. (2018). Useful Application of Plastic Waste in Composite Bricks Manufacturing. Sahyadri International Journal of Research, Volume 4 Issue 1, 12-14.

[8] Ismail, F. Z., Rahmat, M. N., \& Ismail, N. M. (2015). A Study on Absorption Coefficient of Sustainable Acoustic Panels from Rice Husk and Sugarcane Baggase. Advanced Material Research (Vol. 1113), 198-203.

[9] Kleiner, M., \& Tichy, J. (2014). Acoustics of Small Rooms. Boca Raton: CRC Press Taylor \& Francis Group.

[10] Kognole, R., Shipkule, K., Patil, M., Patil, L., \& Survase, U. (2019). Utilization of Plastic waste for making plastic bricks. International Journal of Trend in Scientific Research and Development (IJTSRD), Volume 3 Issue 4, 878-880.

[11] Milios, L., Davani, E. A., \& Yu, Y. (2018). Sustainability Impact Assessment of Indcreased Plastic Recycling and Future Pathways of Plastics Waste Management in Sweden. Recyling Jurnal, 2-21.

[12] Pramono, S. A., Watiningsih, T., \& Rustendi, I. (2014). Sampah sebagai bahan baku pembuatan batu bata. Prosiding Semnas Entrepreneurship (pp. 275-294). Semarang: 
Universitas PGRI Semarang.

[13] Purnawan, I., \& Prabowo, A. (2017). Pengaruh Penambahan Limestone terhadap Kuat Tekan Semen Portland Komposit. Jurnal Rekayasa Proses Vol 11 No 2, 86-93.

[14] Ramadhan, P. (2017). Pengaruh Penggunaan Limbah Plastik LDPE sebagai Agregat Halus pada Batako Beton Ringan. Jurnal Teknik Sipil USU Vol. 6, No. 1, 1-10.

[15] Said, J., \& Sungkono. (2016). Pengolahan sampah plastik dan tanaman enceng gondok menjadi bahan bangunan alternatif hemat energi. Prosiding Temu Ilmiah IPLBI 2016, (pp. 187 - 192).

[16] Sellakutty, D., \& Kirubakaran. (2016). Utilisation of waste plastic in manufacturing of bricks and paver blocks. International Journal of Applied Engineering Research, ISSN 0973-4562 Vol. 11 No.3, 364-368.

[17] Singhal, A., \& Netula, O. (2018). Utilization of plastic waste in manufacturing of plastic sand bricks. 3rd International Conference on New Frontiers of Engineering, Science, Management and Humanities - ISBN: 978-93-87433-29-8 (pp. 207-210). Maharashtra, India: Mahratta Chamber Of Commerce Industries \& Agriculture. 